\title{
Spelling and Phonetic Inconsistencies in English: A Problem for Learners of English as a Foreign/Second Language \\ Nneka Umera-Okeke
}

\section{Abstract:}

Spelling is simply the putting together of a number of letters of the alphabet in order to form words. In a perfect alphabet, every letter would be a phonetic symbol representing one sound and one only, and each sound would have its appropriate symbol. But it is not the case in English. English spelling is defective. It is a poor reflection of English pronunciation as we have not enough symbols to represent all the sounds of English. The problems of these inconsistencies to foreign and second language learners can not be overemphasized. This study will look at the historical reasons for this problem; areas of these inconsistencies and make some suggestions to ease the problem of spelling and pronunciation for second and foreign language learners.

\section{Introduction:}

With the spread of literacy and the invention of printing came the development of written English with its confusing and inconsistent spellings becoming more and more apparent. Ideally, the spelling system should closely reflect pronunciation and in many languages that indeed is the case. Each sound of English language is represented by more than one written letter or by sequences of letters; and any letter of English represents more than one sound, or it may not represent any sound at all. There is lack of consistencies. Commenting on these inconsistencies, Vallins (1954) states: 
Professor Ernest Weekly in The English

Language forcefully and uncompromisingly expresses the opinion that the spelling of English "is so far as its relation to the spoken word is concerned quite crazy..."

At the early stage of writing, say as early as eighteenth century, people did not concern themselves with rules or accepted practices. The general feeling then was as long as a writer's meaning was understood, spelling did not matter. Ephraim Chambers in his Cyclopedia (1743) wrote:

In the English, the orthography is more vague and unascertained, than in any other language we know of. Every author, and almost every printer, has his particular system. Nay, it is scarce so well with us as that: we not only differ from one another; but there is scarcely any that consists with himself. The same word shall frequently appear with two or three different faces in the same page, not to say line. (Metacalfe and Astle, MCMXCV)

Pink and Thomas (1974:5) attributed these inconsistencies to historical reasons which border on the commencement of printing in English in the fifteenth century. They state that the modern English spelling was fixed in the fifteenth century and so it represents the spelling of that century. According to them,

Before that time the scribes had observed no uniformity in the matter of spelling but when printing was invented and books began to multiply, it was found necessary to adhere to some definite system. Thus, the early printers 
Spelling and Phonetic Inconsistencies in English...

produced a system of spelling which has

persisted with few changes, ever since.

Despite the fact that the spelling system of the fifteenth century persisted, English pronunciation on the other hand has undergone many far-reaching changes since Caxton's time which is one of the obvious reasons why there is no correspondence between the written word and the spoken word.

The next reason for the chaotic English spelling was attributed to the French scribes who as early as in the fifteenth century had introduced symbols from their language to represent English sounds. This explains the use of $c$ for $s$ in city, mice, etc; gu for $\mathrm{g}$ in guest, guess, etc; and ou or ow for diphthongal sound in house, cow, etc.

The third reason they gave was the attempt to make the spelling of word retain their etymology. The NormanFrench words "dette and doute", for example, retained their spelling when they were first introduced. They were later written "debt" and "doubt" in order to show their connection with Latin "debitum" and "dubitum". The /b/ has never been pronounced.

\section{Areas of Sound and Spelling Inconsistencies:}

The problems in sound and spelling of English can be grouped under the following headings:

- The same letter does not always represent the same sound.

- The same sound is not always represented by the same letter.

- Some letters are not pronounced at all

- We pronounce sounds in some places where there is no letter

- There are variants of the plural and past tense morpheme: 


$$
(\mathrm{s} / \mathrm{es}) \rightarrow / \mathrm{s}, \mathrm{z}, \mathrm{Iz} / ; \quad(\mathrm{ed}) \rightarrow / \mathrm{d}, \mathrm{Id}, \mathrm{t} /
$$

Attempts should be made to $x$-ray these problems with examples from both the consonants and vowel sounds of English.

\section{Same Letter Different Sounds:}

The same letter does not always represent the same sound in English. Some letters can stand for as many as four different sounds. For instance,

(A) The letter $c$ has no sound equivalent as $c$. It is realized as

i. $\quad / \mathrm{k} /$ as in cup, cat, cotton, bacon, etc. /s/ as in cellar, receive, accent, access.

(B) The letter $g$ is pronounced

i. $\quad / g /$ as in guess, guy, got, guide, gross, etc.

ii /dz/ as in age, agenda, large, huge, etc.

(C) The letter $s$ is realized as

i. /s/ as in sat, sing, socks, etc.

ii. /z/ as in bosom, busy, cousin, easy, feasible, hesitate etc.

iii. $/ \int /$ as in mission, sure, sugar

iv / 3 /as in vision, measure, leisure, usual

(D) The letter $u$ is realized as

i. /u/ as in put, bull, sugar

ii. /aI/ as in buy, guy

iii. /ə/ as in succeed, succumb, suspect

iv. $/ \wedge /$ as in bud, gull, luck, such, study, etc

$\mathrm{v}$. /uə/ as in jury, rural, etc.

(E) The letter $A$ is pronounced

i. $\quad / æ /$ as in sat hand, match 
Spelling and Phonetic Inconsistencies in English...

ii. /a: / as in ask, balm, part, laugh, clerk

iii /D/ as in was, want, wash, because

iv /د:/ as in tall, all, walk

$v / e /$ as in any, many

vi /I/ as in villagge, private, baggagge

\section{Same Sound Different Letters}

Another area of discrepancy between spelling and sound in English is a situation where the same sound is not always represented by the same letter. Such examples are:

(A) The velar plosive $/ \mathrm{k} /$ has different spelling forms as

$\mathrm{k} \quad$ keen, speaker, peak, keg

c cut, cap, act, cattle

cc occasion, according, occur, occupy

ch chemist, stomach

ck pack, back, black

(B) The velar Plosive $/ \mathrm{g} /$ is spelt

g gate, give, bag, go, etc

gg juggle, begged

gh ghost, aghast

(C) The Palato-Alveolar Affricate / d 3 / is represented by the following letters:

j jump, ajar, injury, rejoice

g germ, engine, village

dg budget, bridge, porridge

de grandeur

di soldier

dj adjoin, adjacent

(D) The alveolar nasal / $\mathrm{n} /$ has the following spelling realizations:

$n$

not, ant, run 
(E) The Labio- dental fricative /f/ is also spelt

f fit, leaf, soft, after

ff offer, affair, stiff

gh laughter

ough cough, rough

ph Photo, trophy, graph

This is not peculiar to consonant sounds. A vowel sound can be represented by varying sounds as in:

(F) The sound /e/ is realized in the following spellings:

a many, any

ai said, again

e end send, let, get

ea dead, spread, health

eo leopard, Leonard, Geoffrey

ie friend

ue guess, guest

(G) The sound /u:/ occurs in these spellings:

$\begin{array}{ll}\text { ew } & \text { crew, blew, chew } \\ \text { o } & \text { do, who, womb, pro } \\ \text { oe } & \text { shoe, canoe } \\ \text { oo } & \text { moon, room, food } \\ \text { ou } & \text { group, route, you } \\ \text { u } & \text { blue, rude, June } \\ \text { ui } & \text { juice, fruit } \\ \text { wo } & \text { two }\end{array}$


Spelling and Phonetic Inconsistencies in English...

The diphthongs also have the same chaotic spelling realization. E.g.

/aI/ is spelt:

$\begin{array}{ll}\text { ai } & \text { aisle } \\ \text { ei } & \text { height, neither } \\ \text { eye } & \text { eye } \\ \text { i } & \text { lime, site, silence, tidy, ice } \\ \text { ie } & \text { die, cried, lie } \\ \text { uy } & \text { buy, guy } \\ \text { y } & \text { try, my, shy } \\ \text { ye } & \text { bye, dye } \\ \text { ry } & \text { rhyme }\end{array}$

These examples are to mention but a few.

\section{Silent Letters:}

A lot of English words have silent letters which though written are not meant to be pronounced. Writing such words as one heard them uttered may produce erroneous spellings. They are:

Silent $B$ as in:

Silent $C$ as in:

Silent $D$ as in:

Silent $\mathrm{G}$ as in:

Silent $\mathrm{H}$ as in:

Silent $\mathrm{K}$ as in:

Silent $L$ as in: limb, thumb, comb, numb, womb, debt, subtle, doubt Plumb, dumb, crumb muscle, scene, science, abscess width, handsome, handkerchief, Wednesday, sandpaper gnash, gnaw, gnat, gnome, sign, hang, tongue, reign, thing, feign, diaphragm hour, honest, honour, heir, exhaust, exhibit, vehicle, shepherd ghost, rheumatism know, knit, knock, knight, knee, knife, kneel, knowledge knew, knapsack. knob could, would, should, calf, chalk. Palm, walk, yolk, half, behalf, psalm, talk 
Silent $M$ as in:

Silent $N$ as in:

autumn,

Silent $P$ as in:

empty,

Silent T as in:

Silent U as in:

Silent $\mathrm{W}$ as in: who,

wrapper, mnemonics

Hymn, solemn, condemn, column,

Wednesday /wenzdI/

psalm, psychology, pneumonia, psychic, pseudo, corps, cupboard, Sampson,

receipt, coup, pseudonym

listen, often, castle, butcher, wrestle, deport, rapport, Wretch, ballet, Christmas guess, quest, guard, guide, rouge, colleague, guitar, guinea, vague, guild wretched, wrestling, wrinkle, wrong,

whore, wrath, wrist, wrap, sword,

whom

\section{Inserting Sound where there is no Sound:}

Another sound/spelling problem in English is the intrusion of sound where there is no spelling to indicate that sound. The words could be spelt but the pronunciation is a problem to learners of English. Examples are:

/j/ is pronounced before $u$ in the following words:

Use

Cute

Beauty

Eulogy

Cube

Europe /ju:z/

/kju:t/

/bju:ti/

/ju:lədzi/

/kju:b/

/juərəp/

$/ \mathrm{w} /$ is inserted before the letter $o$ in one, once. 
Spelling and Phonetic Inconsistencies in English...

$/ \mathrm{k} /$ is an extra sound inserted before $s$ in:

$\begin{array}{ll}\text { Accept } & \text { /əksept/ } \\ \text { Access } & \text { /ækses/ } \\ \text { Accident } & \text { /æksident/ } \\ \text { Axle } & \text { /æksl/ } \\ \text { Axis } & \text { /æksis/ } \\ \text { Axe } & \text { /æks/ }\end{array}$

\section{Variants of the Plural and Past Tense Morpheme:}

The next area of variant that is a problem to nonnative speakers of English is variation in the pronunciation of the plural and past tense morpheme. Everyone knows that the regular ways of forming plurals is by the addition of $-s / e s$ to the base word. To form the regular past we also add -ed to the base. When these are added to words, we still have variations in pronunciations of the words formed. Thus we have words like:

/s/ /z/

Cats /kæts/ dogs /dpgz/

Books /buks/ cows /kauz/

laughs /la:fs/ girls /gz:lz/

maps /mæps/ leaves /Ir:vz/
/Iz/

houses /hauziz/

rushes / $\mathrm{r} \wedge \int \mathrm{Iz}$

Dishes /di Jiz/

Benches /bentfiz/

The first column has their plural realized as $/ \mathrm{s} /$; the second /z/ and the third /iz/. The same problem is with the formation of the past. Words with the following sounds are realized, though formed by the addition of the same letters -ed:

Stoned /stər nd/ washed /wDSt/

Played /pleid/ faced /feist/

Begged /begd/ looked /lukt/

Bribed /braibd/ laughed /la:ft/

Dared /deəd/ rushed /r^st/ started /sta:tid/ handed /hædid/ painted /peintid/ divided /divardid/ bolted /bəoltid/ 
While the first column is realized as /d/, the second and third are realized as /t/ and/Id/ respectively. These variations in sounds can bring about erroneous spellings.

\section{Solutions to Spelling/Pronunciation Problems}

Our duty as language teachers is to teach the language and not about the language. A language is what the native speakers say not what some people think they ought to say. If the language is not correct, then what is said is not what is meant. Your triumph in the learning of English to say is always the triumph of education. Pronunciation lessons should be taught from the early stage of education. The failure to represent pronunciation accurately and consistently is, to a large extent, responsible for perennial spelling difficulties among learners of English as a target language.

In spite of evident inconsistencies between the pronunciation and spelling of many English words, there are some discernible patterns. According to Naveh (In Metcalfe and Astle, MCMXCV) "...bad as English spelling may be, it still retains most of the principles of alphabetic writing. It takes only a year or two of study to learn to spell English...." At least the following are consistent:
A. For the plural formation, /s/ occurs after a voiceless sound except the hissing sounds- $/ s, \int, t s /$ as in

i. cats /kæts/
sits /sits/
myths /miø's/
books /buks/ goats /gəots/ stops /stpps/
caps /kæps/ sacks /sæks/ thinks /Oinks/ 
Spelling and Phonetic Inconsistencies in English...

ii. /z/ occurs after voiced sounds, that is, all vowels and voiced consonants except hissing sounds as in :

$\begin{array}{cl}\text { dogs /dngz/ bags /bægz/ } & \text { leaves / li:vz/ } \\ \text { girls /g3: Iz/ boys /bDiz/ } & \text { sings /sinz/ } \\ \text { mills /milz/ cans /kænz/ } & \text { pegs /pegz/ }\end{array}$

iii. /iz/ occurs after the hissing sounds (sibilants) /s, z,

$3, \mathrm{~d}, \mathrm{t} / \mathrm{as}$ in:

houses /hauziz/ beaches /bi:tfiz/ badges /bædzız/

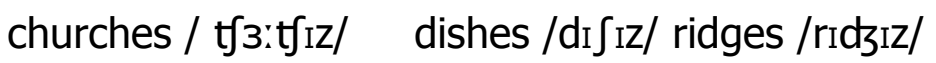
messages /mesidziz/ buses /b^siz/ benches /bentfiz/

B. The -ed added to form the past is also realized as / $d$, $t$, id/ under the following conditions:

i. /t/ or / d/ at the end of a word plus -ed is realized as /id/ as in:

started /sta:trd/ added/ædid/ decided/desardid/ landed /lændid/ painted /peintrd/ provided /provardid/ waited /weitıd/ planted /plætıd/ bolted /bəəltid/

ii. The voiceless sounds /p, k, f, s, $\int, \mathrm{t} /$ plus -ed is realized as /t/:

dreamt/dremt/ knocked/nokt/ clapped /klæpt/ roped /rovpt/ walked /wo:kt/ coughed /knf/ talked /to:kt/ smashed /smæet/ fixed /fikst/ missed/mist/ asked /æskt/ faced /feist/

iii. All other voiced sounds except /d/ plus -ed is realized as /d/

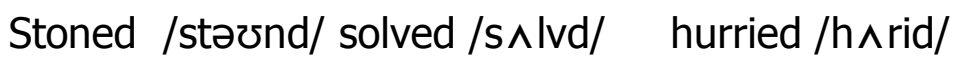

Played /pleid/ cuddled/k^dld/ praised preizd/

Sued /sju:d/ begged /begd/ bribed/braibd/ 
Bowed /baud/ tagged / tægd/ lived /livd/

Other discernible patterns of teaching spelling are:

\section{Dropping or Keeping silent e before added syllables}

1. A verb that ends in silent $e$ drops the $e$ before adding the following suffixes: -ing, -able, -ary, -ition, -ous, ation (suffixes beginning with vowels):

$\begin{array}{llll}\text { advertise } & \text { advertising } & \text { hope } & \text { hoping } \\ \text { arrive } & \text { arrival } & \text { smile } & \text { smiling } \\ \text { issue } & \text { issuing } & \text { dance } & \text { dancing } \\ \text { blue } & \text { bluish } & \text { confuse } & \text { confusing } \\ \text { care } & \text { caring } & \text { true } & \text { truism }\end{array}$

The exceptions to this rule are:

$\begin{array}{ll}\text { dye } & \text { dyeing } \\ \text { be } & \text { being } \\ \text { mile } & \text { mileage } \\ \text { see } & \text { seeing } \\ \text { agree } & \text { agreeing }\end{array}$

2. For all the regular verbs that end in $e$, we add $d$ to form the past:

$\begin{array}{llll}\text { Admire } & \text { admired } & \text { define } & \text { defined } \\ \text { hope } & \text { hoped } & \text { smile } & \text { smiled } \\ \text { dance } & \text { danced } & \text { confuse } & \text { confused } \\ \text { believe } & \text { believed } & \text { imagine } & \text { imagined } \\ \text { love } & \text { loved } & \text { blame } & \text { blamed. }\end{array}$


Spelling and Phonetic Inconsistencies in English...

3. Words ending in silent $e$ drop the $e$ before the suffix $-y$ and th e.g.

$\begin{array}{llll}\text { ease } & \text { easy } & \text { ice } & \text { icy } \\ \text { edge } & \text { edgy } & \text { noise } & \text { noisy } \\ \text { wide } & \text { width } & \text { nine } & \text { ninth } \\ \text { five } & \text { fifth } & & \end{array}$

\section{Exceptions:}

i. When adjective suffixes beginning with $a, 0, u$ are added to words ending in ce or $g e$, the $e$ is kept in order to prevent a change in pronunciation.

$\begin{array}{llll}\text { cage } & \text { cagey } & \text { dice } & \text { dicey } \\ \text { price } & \text { pricey } & \text { notice } & \text { noticeable } \\ \text { marriage } & \text { marriageable } & \text { change } & \text { changeable } \\ \text { advantage } & \text { advantageous } & \text { service } & \text { serviceable } \\ \text { knowledge } & \text { knowledgeable } & & \end{array}$

ii. When the suffix begins with a consonant, the -e is retained:

$\begin{array}{llll}\text { care } & \text { careless/careful } & \text { base } & \text { basement } \\ \text { sincere } & \text { sincerely } & \text { move } & \text { movement } \\ \text { edge } & \text { edgewise } & \text { engage } & \text { engagement } \\ \text { hate } & \text { hateful } & \text { force } & \text { forceful } \\ \text { entire } & \text { entirely } & \text { advertise } & \text { advertisement }\end{array}$

Exceptions:

$\begin{array}{llll}\text { wise } & \text { wisdom } & \text { true } & \text { truly } \\ \text { judge } & \text { judgment } & \text { argue } & \text { argument } \\ \text { subtle } & \text { subtly } & & \end{array}$

4. An adjective that ends in $e$ takes $r$ and $s t$ for the comparative and superlative: 


$\begin{array}{lll}\text { wide } & \text { wider } & \text { widest } \\ \text { late } & \text { later } & \text { latest } \\ \text { large } & \text { large } & \text { largest }\end{array}$

5. But if an adjective ends in $e$, we retain the $e$ to form an adverb ending in $/ y$

polite politely

extreme extremely absolute absolutely

6. If an adjective ends in $/ e$, the e is dropped before the addition of $/ y$

simple simply terrible terribly reasonable reasonably

\section{Spelling Rules for 'ie' and 'ei' Words}

Use $i$ before except after $c$ or when sounded like $a$

'i' before e (ie)

Brief relieve field

relieve chief pierce

retrieve shield piece

grief belief relief

'e' before 'i' (ei)

deceive receive

receipt conceive

ceiling deceit

Exceptions:

leisure neither

either seize 
Spelling and Phonetic Inconsistencies in English...

$\begin{array}{ll}\text { height } & \text { foreign } \\ \text { caffeine } & \text { weird }\end{array}$

\section{E. Doubling of Consonants}

i. When a word ends with vowel plus consonant, the consonant is often doubled before the suffixes -ing/-ed/-er/est, -ish (all suffixes beginning with a vowel).

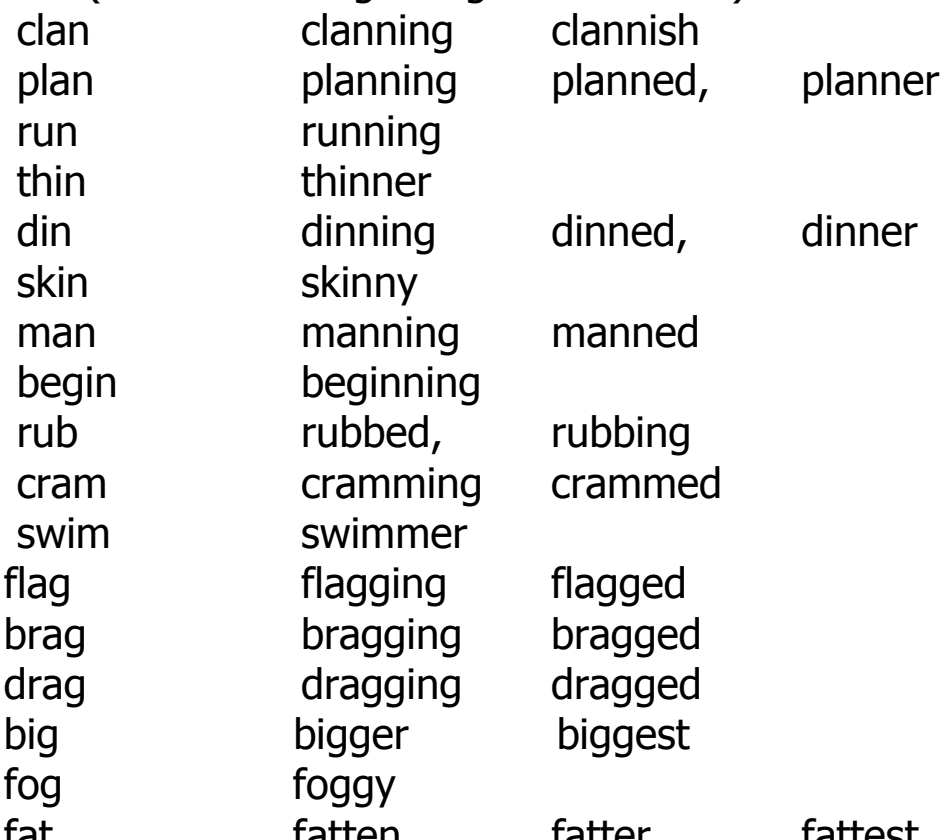

fat

fatten

fatter

fattest

ii. If a word has more than one syllable, we double the consonant at the end only if the final syllable is stressed:

$\begin{array}{llll}\text { preFER } & - & \text { preferring } & \text { preferred } \\ \text { reGRET } & - & \text { regretting } & \text { regretted } \\ \text { perMIT } & - & \text { permitting } & \text { permitted } \\ \text { beGIN } & - & \text { beginning } & \\ \text { adMIT } & - & \text { admitting } & \text { admitted } \\ \text { eQUIP } & - & \text { equipping } & \text { equipped } \\ \text { subMIT } & - & \text { submitting } & \text { submitted }\end{array}$




$\begin{array}{llll}\text { oCCUR } & - & \text { occurring } & \text { occurred } \\ \text { reSIT } & - & \text { resitting } & \\ \text { beSET } & - & \text { besetting } & \\ \text { reFER } & - & \text { referred } & \text { referring }\end{array}$

iii. When the final syllable is not stressed, we do not double the consonant:

VISit

MARvel

DeVELop

BeNEFit

HAPpen

PROfit visiting, marvelous

developing, developed benefiting, benefitable happening, happened profitable, profited, profiting

iv. We do not double the consonant in words that end with two consonants or words which have two vowels before the consonants:

$\begin{array}{llll}\text { start } & - & \text { starting, } & \text { started } \\ \text { help } & - & \text { helping, } & \text { helped } \\ \text { long } & - & \text { longer } & \text { longest } \\ \text { swing } & - & \text { swinging } & \\ \text { return } & - & \text { returned } & \text { returning } \\ \text { harp } & - & \text { harping } & \\ \text { hand } & - & \text { handing } & \text { handy } \\ \text { boil } & - & \text { boiling } & \text { boiled } \\ \text { dream } & - & \text { dreaming } & \end{array}$

v. We also do not double $y$ or $w$ at the end of a word:

stay

grow

new staying

growing

newer stayed

growed

newest 
Spelling and Phonetic Inconsistencies in English...

\section{F. When final ' $y$ ' is changed to ' $i$ '}

The final $y$ in a word changes to $i$ before a vowel except in a suffix beginning with $i$

$\begin{array}{llcl}\text { vary } & \text { variable } & \text { heavy } & \text { heavily } \\ \text { apply } & \text { applied } & \text { hurry } & \text { hurried } \\ \text { italy } & \text { italia } & \text { fancy } & \text { fanciful } \\ \text { happy } & \text { happiness } & \text { defy } & \text { defiant }\end{array}$

$y$ also changes to $i$ before a consonant

$\begin{array}{ll}\text { mystery } & \text { mysterious } \\ \text { marry } & \text { marriage } \\ \text { easy } & \text { easier }\end{array}$

G. Adding -es rather than -s

i. Add $-e s$ to nouns and verbs ending in sibilant sound $-s$, $z$, ch, sh, $x$

$\begin{array}{llll}\text { glass } & \text { glasses } & \text { bench } & \text { benches } \\ \text { box } & \text { boxes } & \text { branch } & \text { branches } \\ \text { class } & \text { classes } & \text { bus } & \text { buses } \\ \text { buzz } & \text { buzzes } & \text { teach } & \text { teaches } \\ \text { dish } & \text { dishes } & & \\ \text { mix } & \text { mixes } & & \end{array}$

ii. Add -es to nouns and verbs ending in $y$ preceded by a consonant; the $y$ changes to $i$ :

$\begin{array}{ll}\text { baby } & \text { babies } \\ \text { carry } & \text { carries } \\ \text { fly } & \text { flies }\end{array}$


But if the $y$ is preceded by a vowel, retain the $y$ and $s$

$\begin{array}{llll}\text { day } & \text { days } & \text { enjoy } & \text { enjoys } \\ \text { monkey } & \text { monkey } & \text { donkey } & \text { donkeys } \\ \text { key } & \text { keys } & \text { valley } & \text { valleys } \\ \text { railway } & \text { railways } & \text { guy } & \text { guys }\end{array}$

iii. Some nouns ending in o take -es.

echo echoes

tomato tomatoes

tornado tornadoes

When preceded by a consonant, have different ways of forming their plural:

(a) Some add s:

$\begin{array}{llll}\text { albino } & \text { albino } & \text { alto } & \text { altos } \\ \text { ego } & \text { egos } & \text { inferno } & \text { infernos } \\ \text { buffalo } & \text { buffalos } & & \end{array}$

(b) Some add es:

$\begin{array}{ll}\text { embargo } & \text { embargoes } \\ \text { potato } & \text { potatoes } \\ \text { calico } & \text { calicoes }\end{array}$

(c) Some have two plurals:

cargo cargoes, cargo

proviso provisos, provisoes

tuxedo tuxedos, tuxedoes

innuendo innuendos, innuendoes 
Spelling and Phonetic Inconsistencies in English...

\section{Conclusion:}

Attempt in this study is not to completely eradicate a foreign accent but the goal of the teacher will be to bring an improvement in their pronunciation especially as regards critical errors responsible for incomprehensibility. Let the students know aspects of their pronunciation and spelling difficulties that result in other people being unable to understand them. Also give them the opportunity to practice aspects of the English sound system which are crucial for their own improvement. With this discernible patterns discussed, good use of both pronouncing and ordinary dictionaries and other forms of vocabulary development, the relationship between English spellings and pronunciation can, after all, not be said to be " quite crazy".

\section{References}

Avery, Peter and Susan Ehrlich. (1997) Teaching American

English Pronunciation. New York: Oxford University Press.

Byrne, Donn. (1976) Teaching Oral English (New Edition). Britain: Longman.

Chukwuma, Helen and Emeka Otagburuagu. (2001) English for Academic Purposes. Nigeria: Africana-FEP Publishers Ltd.

Eyisi, Joy.(2003) A Compendium of Common Errors in the Use of English. Nimo-Nigeria: Rex Charles and Patrick Ltd.

Gimson, A. C.(2000) An Introduction to the Pronunciation of English (3rd Edition). U.S.A.: Edward Arnold (Publishers) Ltd. 
Jones, Daniel. (1995) English Pronouncing Dictionary (4th Ed.) Revised by A.C. Gimson. New Delhi: Universal Book Stall.

Metcalfe, J. E. and C. Astle. (MCMXCV) Correct English.

England: Clarion Publishers.

Pink, Alderton M. \& S. E. Thomas.(1994) English Grammar, Composition and Correspondence (12th Ed.) Reading: Donnington Press.

Sethi, J. \& P. V. Dhamija.(2000) A Course in Phonetics and Spoken English (2nd Ed.) India: Prentice Hall Ltd.

Tench, Paul. Pronunciation Skills. (1981) Malaysia: Macmillan Publishers Ltd. 